\title{
Development of Improved Electrodeposition Method for Repair of Reinforced Concrete Structures
}

\author{
T. Nishida, N. Otsuki, and A. Saito \\ Department of International Development Engineering, Tokyo Institute of Technology
}

\begin{abstract}
Deterioration of reinforced concrete members and their repair methods have been reported in various concrete published reports. Electrodeposition method is one of these repair methods for repairing deteriorated concrete members using an electrochemical mechanism. The purposes of the electrodeposition method are to fill cracks in concrete and to coat the concrete surface by electrodeposits of chemical compounds. This can be accomplished by passing a weak direct current $\left(1.0-3.0 \mathrm{~A} / \mathrm{m}^{2}\right.$ of concrete surface area) between a reinforcing steel bar (cathode) in concrete and an external electrode (anode) located in an external solution near the concrete surface. This method also accomplishes corrosion protection and desalination/re-alkalization, as well as crack closure or surface coating by the electrodeposits. Therefore, it is considered that the electrodeposition is effective in repairing deteriorated concrete members because of chloride attack or carbonation. However, there is very little work on the selection of appropriate electrodeposition conditions such as the type of the cation, its concentration, or type of external electrode for repairing existing reinforced concretes. Therefore, the objective of this paper is to investigate the electrodeposition conditions such as external solution or an external electrode for repairing reinforced concrete structures. From this study, the most suitable electrodeposition conditions to repair deteriorated concrete members are found to be a magnesium acetate-based external solution and an aluminum sacrificial electrode.
\end{abstract}

\section{INTRODUCTION}

Electrodeposition as a crack-repair method was originally developed in Japan during the late 1980s by the Harbor Research Institute and Mitsui Engineering and Shipbuilding Co. Ltd (Yokoda, Sasaki, \& Fukute, 1992). An outline of the application of the electrodeposition method to close cracks in reinforced concrete members in marine environments is shown in Figure 1. The purpose of the electrodeposition method is to fill cracks and to coat the concrete surface with electrodeposits precipitated from cations in seawater to increase its resistance against substance penetrability. These effects are accomplished by providing a weak direct current between a reinforcing steel bar (cathode) in the concrete and an external electrode (anode) placed in seawater serving as an electrolyte solution. In the above-cited reference, its effectiveness in closing the cracks of reinforced concrete members in seawater was confirmed. However, the study on its performance and application for reinforced concrete members on land-based environments is not yet fully explored and documented.

To apply the electrodeposition method to concrete on land-based environments, it is necessary to apply an effective external solution and an artificially introduced electrode. Therefore, in this paper, we investigate the external solution and electrode in three steps based on the flowchart as shown in Figure 2.

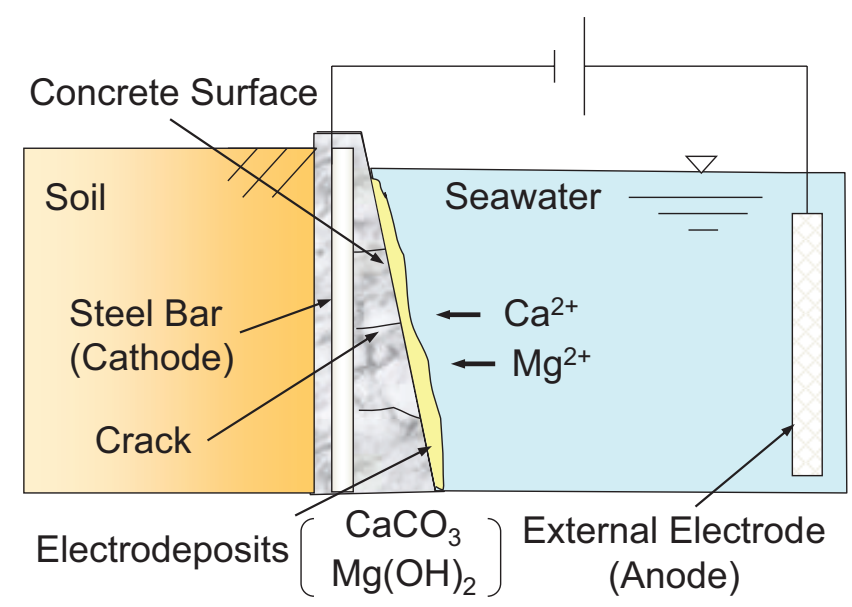

Figure 1. Outline of the application of the electrodeposition method for repairing cracks under seawater.

First, appropriate cations in the external solution to precipitate electrodeposits in the cracks or on the concrete surface were selected based on experimental and theoretical investigations. Second, the external solution was selected from the viewpoint of substance penetrability after the 
electrodeposition repair. Using the above external solution, the investigation of external electrodes was conducted.

\begin{tabular}{|c|}
\hline $1^{\text {st }}$ step: Selection of cations \\
\hline $\begin{array}{l}\text { [Experimental investigation] } \\
\text { To confirm precipitated situations of electrodeposits in cracks } \\
\text { and on concrete surface using several kinds of cations } \\
\text { [Theoretical investigation] } \\
\text { To investigate a mechanism of the electrodeposition on } \\
\text { concrete based on a chemical theory }\end{array}$ \\
\hline 1 Safe, water soluble and un-acidic solutions \\
\hline $2^{\text {nd }}$ step: Selection of external solution \\
\hline $\begin{array}{l}\text { To select the appropriate external solution from viewpoint of } \\
\text { resistance of substance penetrability of concrete after } \\
\text { electrodeposition }\end{array}$ \\
\hline $3^{\text {rd }}$ step: Selection of external electrode \\
\hline $\begin{array}{l}\text { To select an appropriate external electrode for the } \\
\text { electrodeposition using an appropriate solution selected } \\
\text { above investigations }\end{array}$ \\
\hline
\end{tabular}

Figure 2. Flowchart of this study.

\section{SELECTION OF CATIONS}

\subsection{Outline of specimen}

In this investigation, Type-A mortar specimens with the size $40 \mathrm{~mm} \times 40 \times 160 \mathrm{~mm}$ were used. The outline and mix proportion of Type-A specimens are shown in Figure 1 and Table 1, respectively. These specimens were used for a sectional investigation of the cations in the external solution. The steel bar was connected by welding, and the lead wire was soldered firmly to the steel. A crack with $0.5 \mathrm{~mm}$ width was applied by a three-point bending load at the middle of the exposure surface. The mortar surfaces, except an exposure surface, were covered with epoxy resin. The water/ cement ratio and the sand/cement ratio of Type-A specimens were $50 \%$ and 2.5 , respectively. Materials used in above specimens were as follows: Cement Association of Japan (CAJ) research cement (density: $3.17 \mathrm{~g} / \mathrm{cm}^{3}$, specific surface area: $3270 \mathrm{~cm}^{2} / \mathrm{g}$ ) was used as the cement. River sand (SSD specific gravity: $2.62 \mathrm{~g} / \mathrm{cm}^{3}$, water absorption ratio: $1.73 \%$, fineness modulus: 2.80 ) was used as fine aggregate. The steel bars embedded in Type-A specimens were of $6 \mathrm{~mm}$ diameter and circular shape.

Table 1. Mix proportion of Type-A specimens $\left(\mathrm{kg} / \mathrm{m}^{3}\right)$.

\begin{tabular}{ccc}
\hline W & C & S \\
\hline 281 & 564 & 1407 \\
\hline
\end{tabular}

\subsection{Charging method to specimens}

The charging method for Type-A specimens is shown in Figure 3. Type-A specimens were submerged
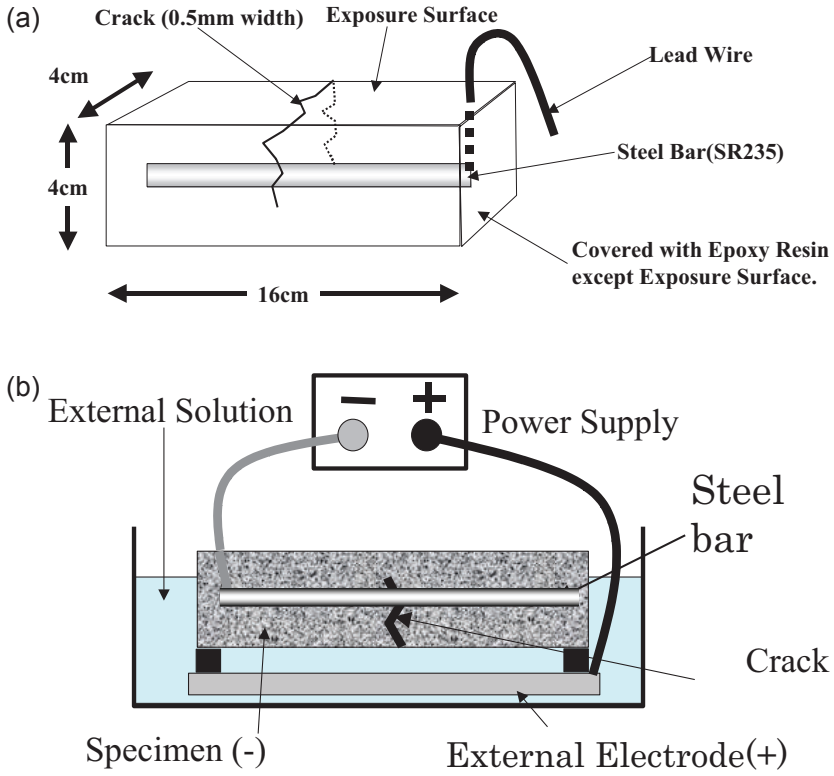

Figure 3. (a) Outline of Type-A specimens used for the selection of cations in an external solution. (b) Charging method to Type-A specimens with crack.

in an external solution containing the following cations: $\mathrm{Mg}^{2+}\left(\mathrm{MgCl}_{2}\right), \mathrm{Zn}^{2+}\left(\mathrm{ZnSO}_{4}\right), \mathrm{Cu}^{2+}\left(\mathrm{CuCl}_{2}\right)$, $\mathrm{Na}^{+}\left(\mathrm{NaHCO}_{3}\right)$, and $\mathrm{Ag}^{+}\left(\mathrm{AgNO}_{3}\right)$. Then, a current density of $1.0 \mathrm{~A} / \mathrm{m}^{2}$ (vs. mortar surface) was applied between the external electrode and the steel bar in Type-A specimens.

\subsection{Results and discussion using Type-A specimens}

The appearances of electrodeposits on the mortar surface with a crack are shown in Figures 4(a)-(e). From these figures, when the external solution contained cations of $\mathrm{Mg}^{2+}, \mathrm{Zn}^{2+}$, or $\mathrm{Cu}^{2+}$, electrodeposition could make up the crack and the exposure surface was covered with electrodeposits. When the external solution contained the cations of $\mathrm{Ag}^{+}$, electrodeposition could cover only the cracked part. On the other hand, in the case of the external solution with $\mathrm{Na}^{+}$, electrodeposits could not be precipitated in the crack or on the exposure surface.

The cross-section of electrodeposits in the crack is shown in Figure 5. From this figure, it can be said that the cross-section of electrodeposits in the crack differs depending on the cations included in the external solution. When $\mathrm{Mg}^{2+}$ or $\mathrm{Zn}^{2+}$ was used, precipitates were formed in the crack. However, when $\mathrm{Cu}^{2+}$ or $\mathrm{Ag}^{+}$was used, electrodeposits only covered the crack without precipitating in the crack.

From the above experimental results, it can be concluded that it is better for the external solution for the electrodeposition to contain $\mathrm{Mg}^{2+}$ or $\mathrm{Zn}^{2+}$ cations. The mechanisms of electrodeposition in concrete are discussed in next section. 
(a) $\mathrm{Mg}^{2+}$

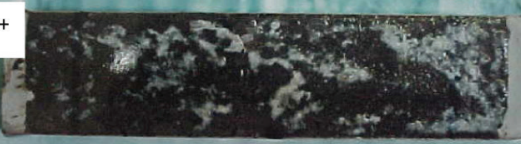

(c) $\mathrm{Cu}^{2+}$

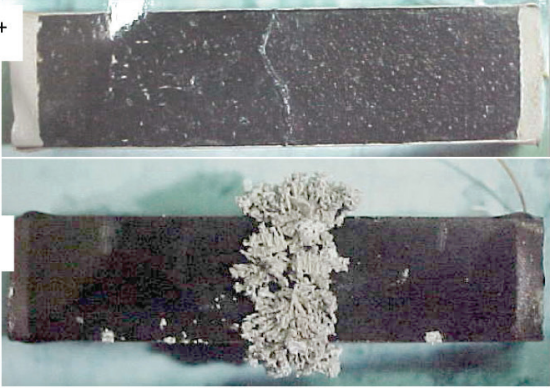

(b) $Z n^{2}$

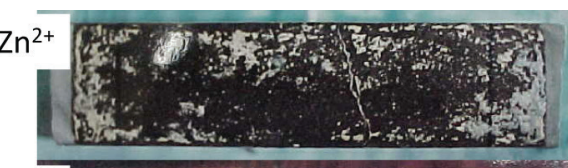

(d) $\mathrm{Na}$

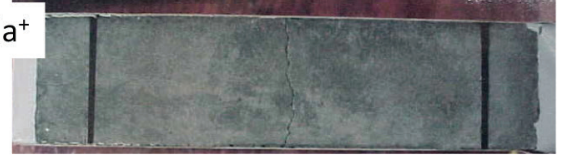

The size of exposure surface of each specimen was $40 \times 160 \mathrm{~mm}$.

Size of crack was $0.5 \mathrm{~mm}$ and the crack was introduced at the center of exposure surface by 3point bending

Figure 4. Appearance of electrodeposits on exposure surface.
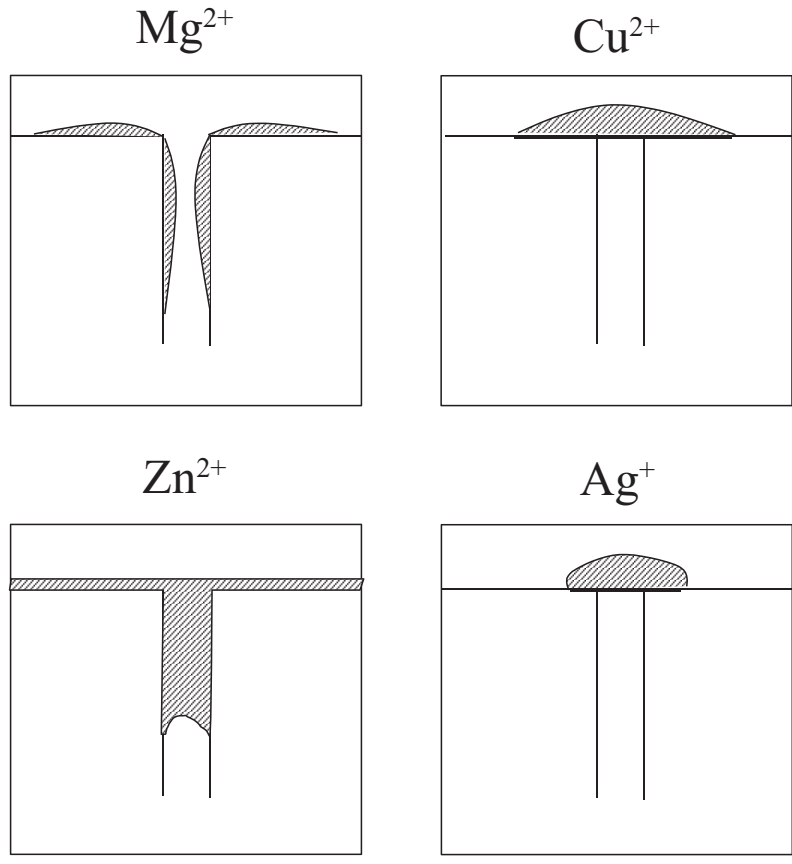

Figure 5. Cross sections of electrodeposits in the crack. (Shaded part shows electrodeposits)

\section{MECHANISM OF ELECTRODEPOSITION IN CONCRETE}

It is considered that the electrodeposits form from two phenomena: migration and precipitation. The first phenomenon deals with the migration of ions toward the concrete surface by means of an electrochemical process accomplished through the application of a weak direct current between the steel bars in concrete and an external electrode situated outside the concrete in the presence of an external solution. The second phenomenon deals with the precipitation of cations such as $\mathrm{Mg}^{2+}$ or $\mathrm{Zn}^{2+}$ in cracks or on the concrete surface as a result of chemical reaction and the increase of cation concentration due to charging. The schematic

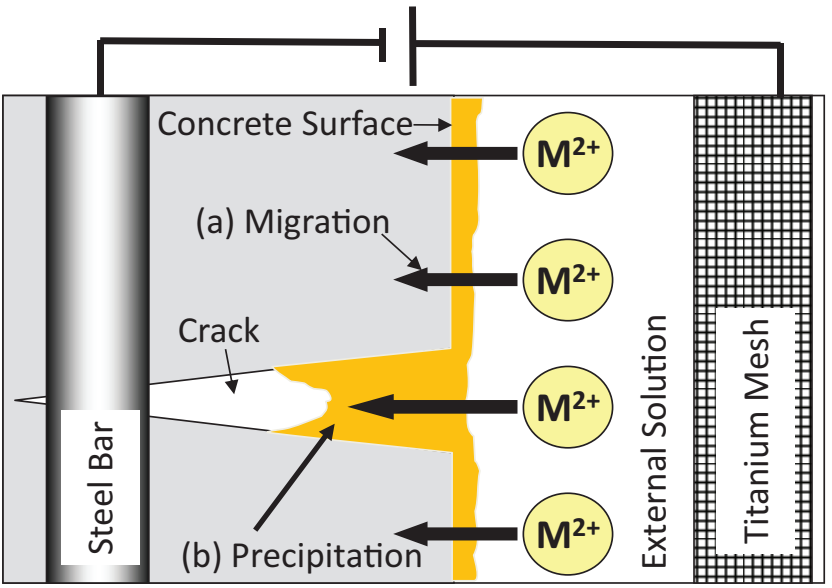

Figure 6. Mechanisms of electrodeposition in a crack and on the concrete surface.

diagram of the electrodeposition process is shown in Figure 6.

The precipitating reaction of the electrodeposits from ions existing in concrete and the external solution is expressed by the following equations:

$$
\begin{aligned}
& \mathrm{M}^{2+}+2 \mathrm{OH}^{-} \Leftrightarrow \mathrm{M}(\mathrm{OH})_{2} \downarrow \\
& \mathrm{M}^{2+}+2 \mathrm{OH}^{-} \Leftrightarrow \mathrm{MO} \downarrow+\mathrm{H}_{2} \mathrm{O}
\end{aligned}
$$

where $\mathrm{M}^{2+}$ is a cation such as $\mathrm{Mg}^{2+}, \mathrm{Zn}^{2+}$, or $\mathrm{Ca}^{2+}$ located in the external solution; $\mathrm{M}(\mathrm{OH})_{2}$ is a hydroxide such as $\mathrm{Mg}(\mathrm{OH})_{2}$ or $\mathrm{Ca}(\mathrm{OH})_{2}$; and $\mathrm{MO}$ is an oxide such as $\mathrm{ZnO}$.

In general, the precipitating reactions proceed between the cations in the external solution and the anions generated at the cathode (steel bar). The products after the precipitating reactions (electrodeposits) are poorly soluble substances, and these electrodeposits are in equilibrium in the solution. From the above conditions, the following equations can be derived (Grant, 1969):

$$
\left[\mathrm{M}^{2+}\right] \cdot\left[\mathrm{OH}^{-}\right]^{2}=\mathrm{K}_{\mathrm{sp}}
$$


where $K_{\mathrm{sp}}$ is the solubility of the product. By taking the logarithm on both sides of the above equation and considering the ion product of water, Equation (3) can be modified into

$$
\begin{aligned}
\log \left[\mathrm{M}^{2+}\right] & =-2 \log \left[\mathrm{OH}^{-}\right]+\log K_{\mathrm{sp}} \\
& =28-2 \mathrm{pH}+\log K_{\mathrm{sp}}
\end{aligned}
$$

As shown in Equation (4), the precipitation of cations depends on the $\mathrm{pH}$ of the solution and the solubility of the product of electrodeposits. Figure 7 shows the relationship between the cation concentration and $\mathrm{pH}$ in a given solution. The boundary line (a) shown in Figure 7 is derived from Equation (4). As shown in this figure, cations may only exist as ions within the lower region of boundary line (a), but they precipitate beyond this line, because these hydroxides or oxides have poor solubility in the solution. The influence of $\mathrm{pH}$ and the solubility of the product on the precipitating reaction of the electrodeposits can be considered as follows.

Related to $\mathrm{pH}$ of the external solution, the situation where the $\mathrm{pH}$ equals to 8.0 with the cation concentration of $0.10 \mathrm{~mol} / \mathrm{l}(\mathrm{I})$ is considered. When the concentration of cations rises from the initial stage to above the boundary line (a) (the reaction being represented by an arrow in Figure 7), this indicates that cations cannot exist as ions in the external solution; instead, they will precipitate as a result of their poor solubility in the solution. For cations located in the external solution, the cations migrate toward the cracks and the concrete surface by the direct current. As a result, higher concentration of cations in the crack and near the concrete surface results than during the initial stage. Thus, cations cannot exist as ions in the crack and near the concrete surface because of the said condition. With the $\mathrm{pH}$ equal to 6.0 and a cation concentration of $0.10 \mathrm{~mol} / \mathrm{l}$ (II), the result is also shown in Figure 7. The black region in the arrows over boundary line (a) representing the amount of electrodeposits is lager for a $\mathrm{pH}$ equal to 8.0 than for a $\mathrm{pH}$ equal to 6.0. This suggests that the number of ions precipitating at a high $\mathrm{pH}$ is larger than that at a low $\mathrm{pH}$

On the other hand, the influence of the solubility of the product on the precipitating reaction of the electrodeposits is considered. Table 2 shows the solubility of the products of the expected electrodeposits from cations. From Table 2 and the precipitation situation of electrodeposits such as in Figures 4 or 5 , soluble electrodeposits such as $\mathrm{NaOH}$ cannot be found in the cracks or on the concrete surface. On the other hand, insoluble electrodeposits such as $\mathrm{Cu}(\mathrm{OH})_{2}$ or $\mathrm{Ag}$ can precipitate on the concrete surface but these cannot precipitate in the cracks as shown in Figure 5. It is considered that the

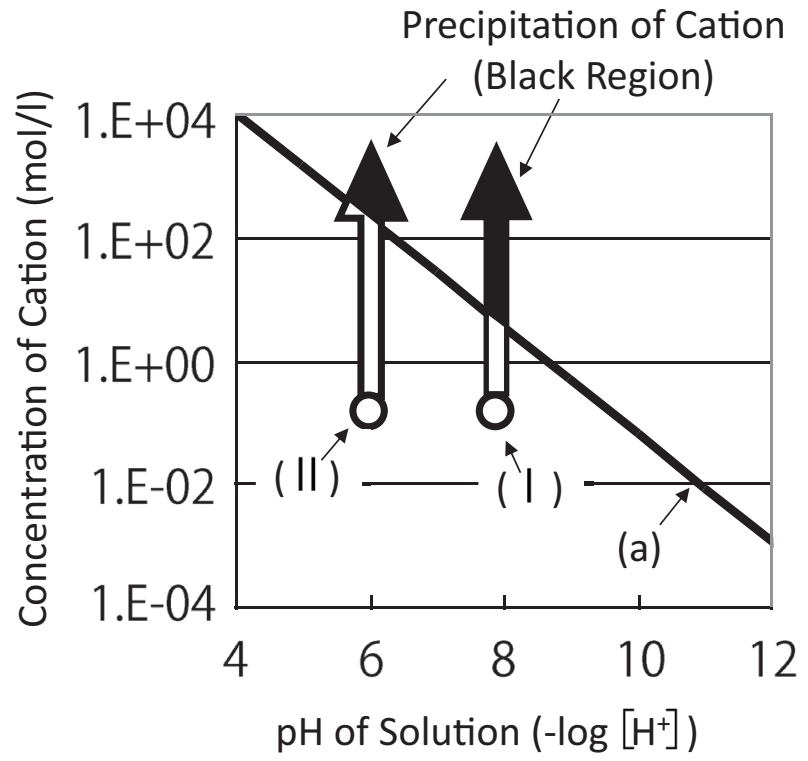

Figure 7. Relationship between the concentration of cations and the $\mathrm{pH}$ of the solution (black region in arrows means precipitation of cations).

\begin{tabular}{|c|c|c|}
\hline Type of cation & $\begin{array}{c}\text { Expected } \\
\text { electrodeposits }\end{array}$ & $\begin{array}{l}\text { Solubility of the } \\
\text { electrodeposits }\end{array}$ \\
\hline $\mathrm{Na}^{+}$ & $\mathrm{NaOH}$ & Soluble \\
\hline $\mathrm{Mg}^{2+}$ & $\mathrm{Mg}(\mathrm{OH})_{2}$ & $\begin{array}{c}1.2 \times 10^{-11} \\
\text { (poorly soluble) }\end{array}$ \\
\hline $\mathrm{Zn}^{2+}$ & $\mathrm{ZnO}$ & $\begin{array}{c}3.0 \times 10^{-16} \\
\text { (poorly soluble) }\end{array}$ \\
\hline $\mathrm{Ca}^{2+}$ & $\mathrm{Ca}(\mathrm{OH})_{2}$ & $\begin{array}{c}5.5 \times 10^{-5} \\
\text { (poorly soluble) }\end{array}$ \\
\hline $\mathrm{Cu}^{2+}$ & $\mathrm{Cu}(\mathrm{OH})_{2}$ & Insoluble \\
\hline $\mathrm{Ag}^{+}$ & $\mathrm{Ag}$ & Insoluble \\
\hline
\end{tabular}

Table 2. Solubility products of expected electrodeposits.

rapid precipitation of electrodeposits such as $\mathrm{Cu}(\mathrm{OH})_{2}$ or $\mathrm{Ag}$ inhibits the migration of cations into the cracks, and therefore only the concrete surface is covered by the electrodeposits. So it can be concluded that poorly soluble compounds such as $\mathrm{Mg}(\mathrm{OH})_{2}, \mathrm{ZnO}$, and $\mathrm{Ca}(\mathrm{OH})_{2}$ can precipitate in cracks and on the concrete surface as electrodeposits.

Based on the result of the chemical reaction as mentioned above, it was theoretically proved that better precipitation of electrodeposits can be obtained in the case of high $\mathrm{pH}$ of the external solution and the cations that provide poorly soluble compounds as electrodeposits.

\section{SELECTION OF EXTERNAL SOLUTION}

\subsection{Outline of specimen}

The specimen (Type-B) and the mix proportion of concrete are shown in Figure 8 and Table 3 , 


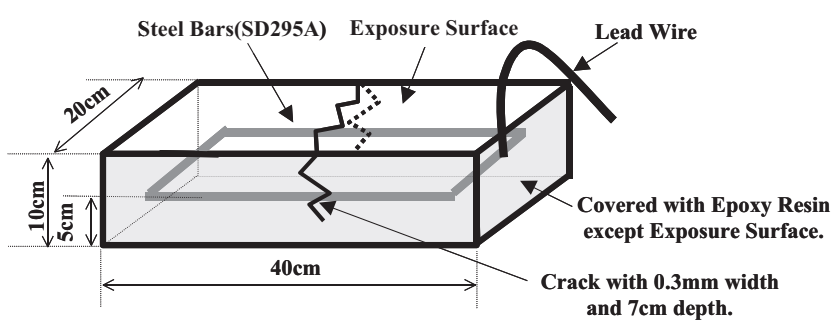

Figure 8. Outline of Type-B specimens used for the selection of cations in the external solution.

Table 3. Mix proportion of Type-B specimens $\left(\mathrm{kg} / \mathrm{m}^{3}\right)$.

\begin{tabular}{ccccc}
\hline $\mathbf{W}$ & $\mathbf{C}$ & $\mathbf{S}$ & $\mathbf{G}$ & $\mathbf{A d}^{*}$ \\
\hline 160 & 364 & 747 & 1046 & 4.02 \\
\hline
\end{tabular}

$\mathrm{Ad}^{*}$ : Water reducing agent

Table 4. External solutions and solution concentrations used.

\begin{tabular}{|c|c|c|}
\hline \multirow[t]{4}{*}{ External Solution } & $\mathrm{Mg}^{2+}$ & 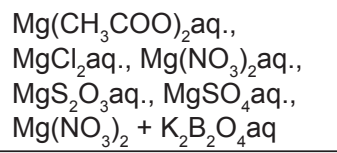 \\
\hline & $\begin{array}{l}\mathrm{Mg}^{2+} \\
+\mathrm{Ca}_{2+} \\
\end{array}$ & $\mathrm{Ca}_{m} \mathrm{Mg}_{n}\left(\mathrm{CH}_{3} \mathrm{COO}\right)_{(m+n)}$ aq. \\
\hline & $\mathrm{Ca}^{2+}$ & $\begin{array}{l}\mathrm{Ca}\left(\mathrm{CH}_{3} \mathrm{COO}\right)_{2} \text { aq., } \\
\mathrm{Ca}\left(\mathrm{NO}_{2}\right)_{2} \text { aq., } \mathrm{Ca}\left(\mathrm{NO}_{3}\right)_{2} \text { aq. }\end{array}$ \\
\hline & $\mathrm{Zn}^{2+}$ & $\mathrm{ZnSO}_{4}$ aq. \\
\hline Concentration $(\mathrm{mol} / \mathrm{l})^{*}$ & \multicolumn{2}{|c|}{$0.01,0.05,0.10,0.20,0.50,1.0$} \\
\hline
\end{tabular}

*All external solutions investigated were with $0.10 \mathrm{~mol} / \mathrm{l}$ of solution concentration. In order to investigate the influence of the anion on electrodeposition effect, six levels of solution concentration were investigated in the case of $\mathrm{Mg}\left(\mathrm{CH}_{3} \mathrm{COO}\right)_{2}$ aq. and $\mathrm{Mg}\left(\mathrm{NO}_{3}\right)_{2}$ aq.

respectively. Type-B specimens were used to select the external solution. Each steel bar was connected by welding, and the lead wire was soldered firmly to the steel bar. A crack of $0.3 \mathrm{~mm}$ width was applied by a three-point bending load. The concrete surfaces, except the exposure surface, were coated with epoxy resin. The water/cement ratio, the water content, and the compressive strength at the age of 28 days were $0.44,160 \mathrm{~kg} / \mathrm{m}^{3}$, and $40.7 \mathrm{MPa}$, respectively.

\subsection{Charging method to specimens}

The charging method for Type-B specimen was same as shown in Figure 3. The external solutions and solution concentrations investigated in this section are shown in Table 4. From the results of the previous section, the cations $\mathrm{Mg}^{2+}, \mathrm{Zn}^{2+}$, and $\mathrm{Ca}^{2+}$ are considered as appropriate in the external solution. When these external solutions were selected, the following conditions were considered:

1. It is not a strong acid.

2. It is safe to use as an external solution.

3. It is soluble in water.
Also, the $\mathrm{pH}$ of external solution during charging decreases with increasing charging periods because of the electrolysis of water as shown in Equation (5).

$$
2 \mathrm{H}_{2} \mathrm{O} \rightarrow \mathrm{O}_{2}+4 \mathrm{H}^{+}+4 e^{-}
$$

According to the previous investigation, it is considered that a lower $\mathrm{pH}$ results in less precipitation of electrodeposits, so countermeasures against the $\mathrm{pH}$ drop are required. Therefore, the buffer effect of the salt of a weak acid is also investigated here. The buffer effect in a solution is expressed by following equation:

$$
\mathrm{A}^{-}+\mathrm{H}^{+} \Leftrightarrow \mathrm{AH}
$$

where $\mathrm{A}^{-}$is a weak acid such as $\mathrm{CH}_{3} \mathrm{COO}^{-}$.

\subsection{Measurement items}

During the charging for electrodeposition, the $\mathrm{pH}$ and cation concentration of solution were measured using a $\mathrm{pH}$ meter and an ion chromatograph, respectively.

After charging, to assess the situation of the crack closure by electrodeposits, the exposed surface of the concrete was carefully examined. Then, the ratio of the crack closure, the closure depth, and deposition depth were measured. The ratio of crack closure is defined as the ratio of the length of the crack closure to the total crack length. On the other hand, the closure depth and deposition depth were defined as shown in Figure 9. The specimen was cut longitudinally parallel to the position of the steel bar, and the crack closure depth and the deposition depth were observed and measured using a microscope. Crack closure depth refers to the maximum depth totally closed by electrodeposits, and deposition depth refers to the maximum depth that the electrodeposits have reached within the crack.

Also, to determine the resistance of substance penetrability after electrodeposition, the carbonation test was conducted. Specimens after charging were exposed to accelerated carbonation condition for 14 days in a controlled environment of $60^{\circ} \mathrm{C}$ and $70 \%$ relative humidity with $10 \% \mathrm{CO}_{2}$ concentration. After the 14th day, the concrete specimens were cut

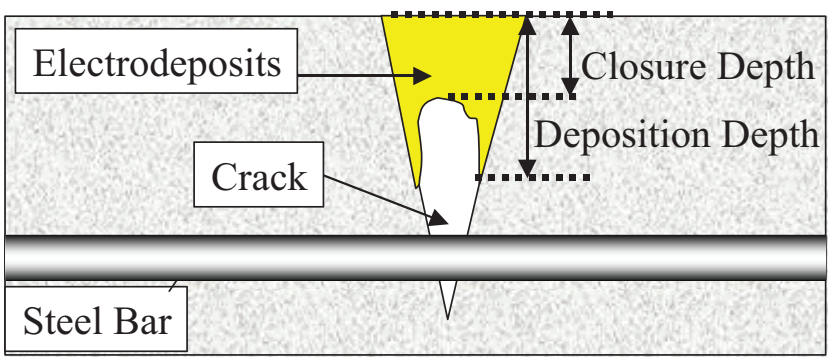

Figure 9. Measurement method of closure depth and deposition depth of electrodeposit in cracks. 
longitudinally parallel to the position of the reinforcing steel bar. Then, phenolphthalein with $1.0 \%$ ethanol solution was sprayed on the cut surface of the specimens. The region that changes into magenta color was defined as the carbonation depth, and the depth was measured using a Vernier calipers.

\subsection{Result and discussion using Type-B specimens}

The relationship between the $\mathrm{pH}$ of the external solution and the period of charging is shown in Figure 10. As shown in the figure, it was confirmed that the $\mathrm{pH}$ decreased as the charging period increased especially when $\mathrm{Mg}\left(\mathrm{NO}_{3}\right)_{2}$ aq. was used as an external solution. However, no $\mathrm{pH}$ decrease of the solution was observed in the case of using external solutions with the salt of a weak acid such as $\mathrm{Mg}\left(\mathrm{CH}_{3} \mathrm{COO}\right)_{2}$ aq. or with a halide such as $\mathrm{MgCl}_{2}$, which have a buffer effect. So, as shown in Equation (6), the salt of a weak acid absorbs $\mathrm{H}^{+}$thus resulting in a constant $\mathrm{pH}$ in the external solution. On the other hand, in case of the halide, $\mathrm{H}^{+}$cannot be generated because of the generation of halogen gas.

The relationship between the crack closure depths or deposition depths and the $\mathrm{pH}$ of the external solution after electrodeposition is shown in Figure 11. From this figure, the crack closure depth and deposition depth, which indicate the quantity of the electrodeposits, increase as the $\mathrm{pH}$ of the external solution increases. This result agrees with the estimation obtained in the theoretical investigation.

In the above discussions, the precipitation condition of the electrodeposition was discussed. In this study, the resistance against substance penetrability after precipitation of the electrodeposits is discussed. Figure 12 shows the relationship between the carbonation depth at the crack and the type of external solution. Based on this graph, the depth

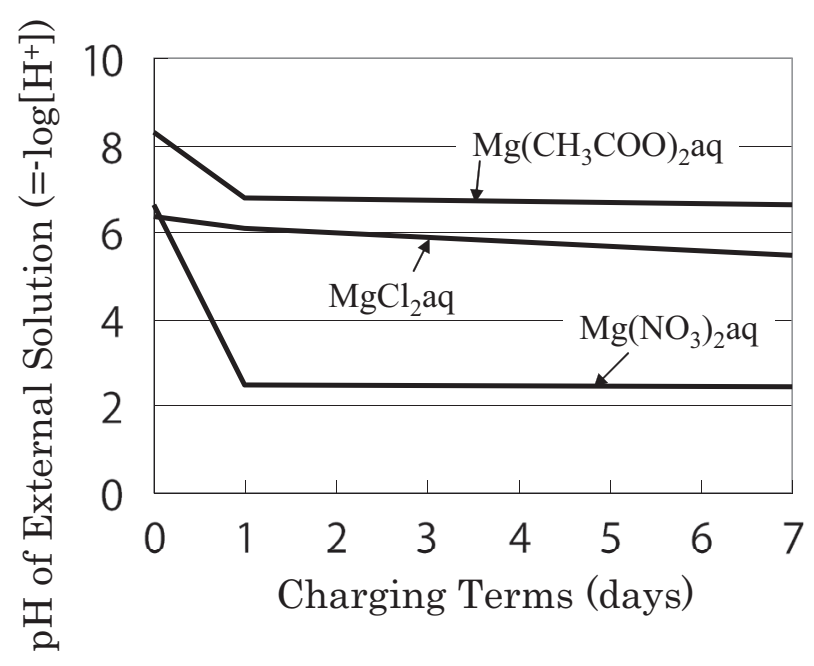

Figure 10. $\mathrm{pH}$ decreases in external solution with charging.

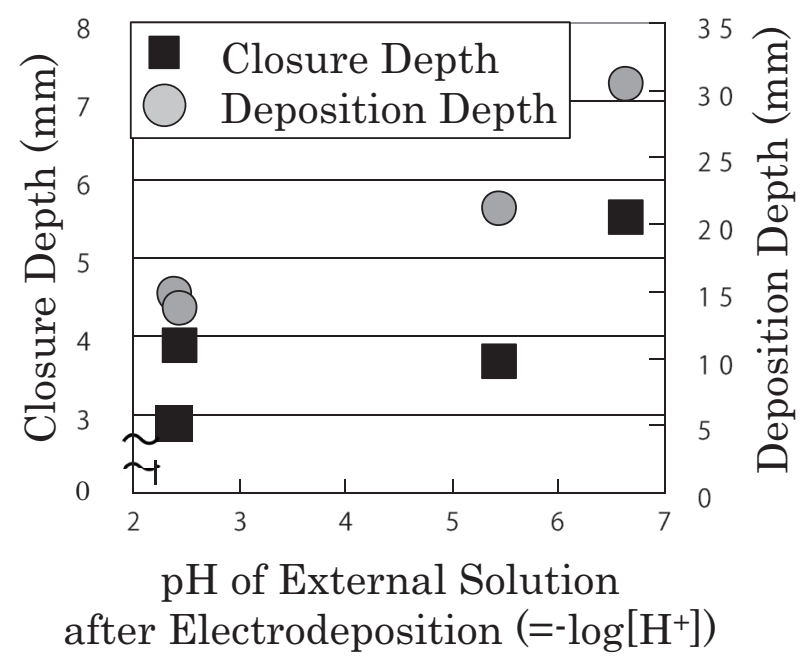

Figure 11. Influence of $\mathrm{pH}$ in the external solution after charging on the closure depth or the deposition depth in cracks.

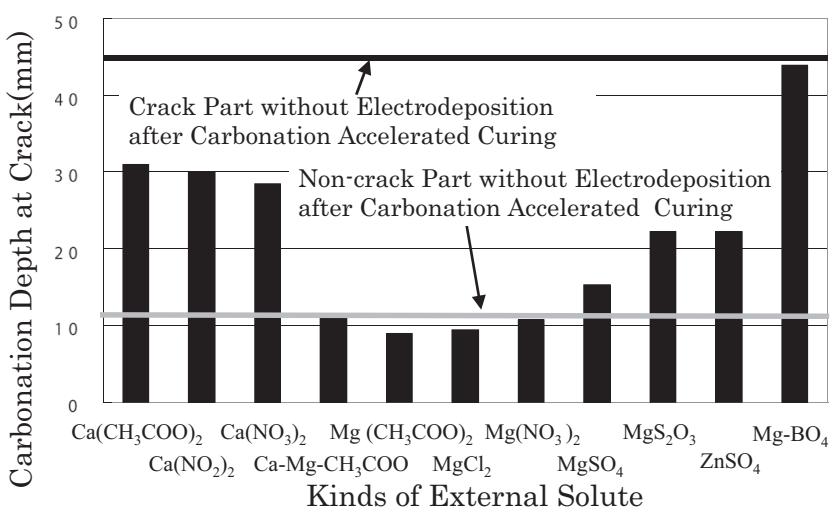

Figure 12. Carbonation depth at crack after electrodeposition with different external solutions.

of carbonation at the crack is influenced by the type of external solution. Especially in the case of $\mathrm{Mg}\left(\mathrm{CH}_{3} \mathrm{COO}\right)_{2}, \mathrm{Ca}_{m} \mathrm{Mg}_{n}\left(\mathrm{CH}_{3} \mathrm{COO}\right)_{(m+n)}$, and $\mathrm{MgCl}_{2}$ as external solutions, the carbonation depth was smaller. Moreover, closure depths using these types of external solutions were deeper because they prevented a decrease in the $\mathrm{pH}$ of the solution. On the other hand, for external solutions containing $\mathrm{Mg}^{2+}$, the carbonation depth was smaller compared to that of the other types of solution. Based on the above-mentioned results, it is concluded that the use of $\mathrm{Mg}\left(\mathrm{CH}_{3} \mathrm{COO}\right)_{2}$ as the external solution has the highest resistance effect against carbonation in concrete.

The relationship between the carbonation depth at the crack and the cation concentration is shown in Figure 13. As shown in this figure, the carbonation depth is very small as a result of using a $0.10 \mathrm{~mol} / \mathrm{l}$ cation concentration. This can be explained by Table 5 and Figure 14. From Table 5 , it can be confirmed that the ratio of crack closure decreases (becomes worse) when the solution concentration 


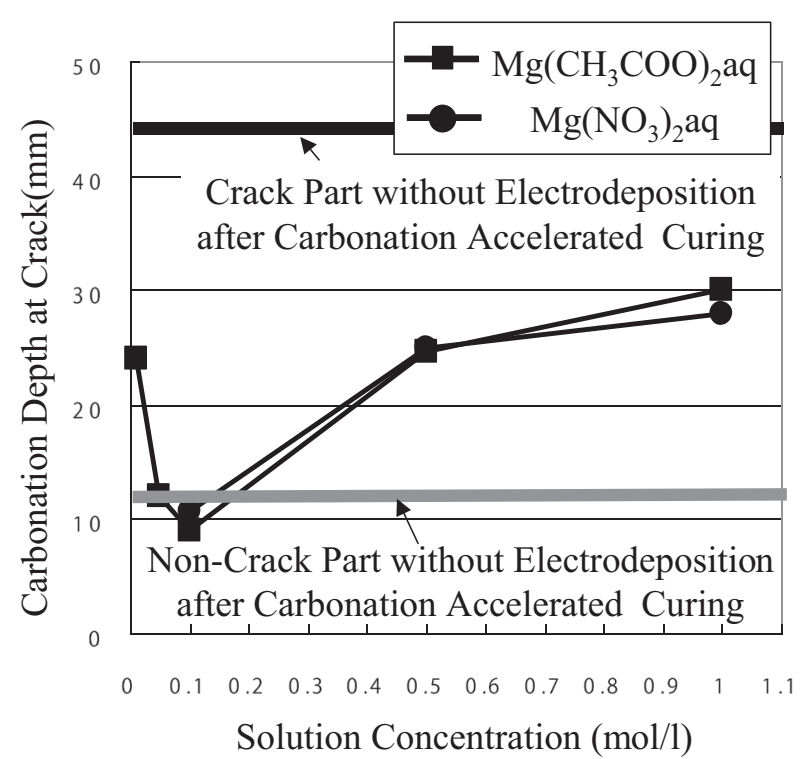

Figure 13. Influence of solution concentration on carbonation depth at crack after electrodeposition.

Table 5. Closure situation of crack and porosity of electrodeposits depending on the solution concentration in the case of $\mathrm{Mg}\left(\mathrm{CH}_{3} \mathrm{COO}\right)^{2}$ as external solution.

\begin{tabular}{lccc}
\hline Solution concentration (mol/l) & 0.05 & 0.1 & 0.5 \\
Ratio of crack closure (\%) & 100 & 100 & 95 \\
Closure depth (mm) & 4.2 & 5.5 & 5.8 \\
Porosity of electrodeposits (cc/g) & 0.069 & 0.073 & 0.113 \\
\hline
\end{tabular}

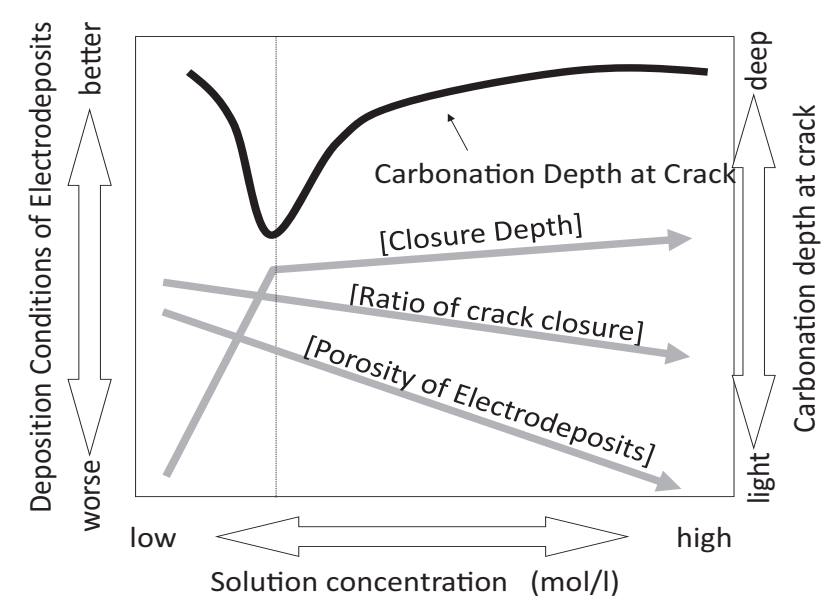

Figure 14. Schematic figure of the influence of deposition conditions on carbonation depth at crack after electrodeposition.

increases. On the other hand, the closure depth and porosity of electrodeposits increase when the solution concentration increases. This means that the closure depth becomes better but the porosity of electrodeposits becomes worse with increasing solution concentration. These relationships are illustrated in Figure 14. Based on the conditions mentioned above, the use of a concentration of $0.10 \mathrm{~mol} / \mathrm{l}$ cations has the highest depression effect against carbonation in concrete.

\subsection{Selection of appropriate external solution}

From above investigations and discussion, it is concluded that the appropriate solution type and its concentration as the external solution for electrodeposition are $\mathrm{Mg}\left(\mathrm{CH}_{3} \mathrm{COO}\right)_{2}$ and $0.10 \mathrm{~mol} / \mathrm{l}$, respectively.

\section{SELECTION OF EXTERNAL ELECTRODE}

\subsection{Outline of specimen}

Mortar specimens (Type-C) were cast with ordinary Portland cement. The water/cement ratio of Type-C specimens was 0.5 . Also, the sand/cement ratio was 2.5. The details of specimen are the same as those of Type-A specimen. The steel rebar was embedded with a $15-\mathrm{mm}$ mortar cover. A crack of $0.4 \pm 0.1 \mathrm{~mm}$ width was induced in specimen along the steel bar.

\subsection{Charging method to specimens}

Electrodeposition was performed on these mortar specimens for 14 days with $2.0 \mathrm{~A} / \mathrm{m}^{2}$ current density. The direct current was applied between the external electrode (anode) in the external solution and the steel bar in mortar specimen (cathode). Electrodeposition conditions investigated in the process of external electrode selection are shown in Table 6.

\subsection{Measurement items}

To select the appropriate external electrode, the ratio of surface coating, deposition depth, $\mathrm{Cl}^{-}$penetration depth, and erosion of the external electrode were evaluated.

The ratio of surface coating is defined as the ratio of covered area by electrodeposits after electrodeposition and the exposure surface area. Also, the deposition depth is defined as shown in Figure 9. These parameters were used for the evaluation of the precipitation of electrodeposits after charging.

In this study, titanium is a stable material against dissolution of the metal during charging, while iron or alumina is easily eroded. The eroded metals become cations in the external solution and these cations migrate to concrete surface because of the electrical potential provided by the direct current. To evaluate this phenomenon, the weight change of external electrode before and after electrodeposition was measured.

On the other hand, to evaluate the substance penetrability after electrodeposition, the $\mathrm{Cl}^{-}$ penetration depth was measured after submerging the electrodeposited specimen in $10 \mathrm{wt} \% \mathrm{NaCl}$ solution for 1 week. The depth of $\mathrm{Cl}^{-}$penetration was measured using the silver nitrate method (Otsuki, Nagataki, \& Nakashita, 1992). Also, the quantity of $\mathrm{Cl}^{-}$around the steel bars was measured based on Figure 15. 
Table 6. Combinations of external electrodes and external solutions.

\begin{tabular}{lcl}
\hline & $\begin{array}{c}\text { Type of external } \\
\text { electrode }\end{array}$ & \multicolumn{1}{c}{ solution } \\
$\mathrm{Fe}-\mathrm{Mg}$ & $\mathrm{Fe}$ & $\mathrm{Mg}\left(\mathrm{CH}_{3} \mathrm{COO}\right)_{2} 0.10 \mathrm{~mol} / \mathrm{l}$ \\
$\mathrm{Fe}-\mathrm{Mg}+\mathrm{Al}$ & $\mathrm{Fe}$ & $\begin{array}{l}\mathrm{Mg}\left(\mathrm{CH}_{3} \mathrm{COO}\right)_{2} 0.10 \mathrm{~mol} / \mathrm{l} \text { with } \\
\text { colloidal alumina }\end{array}$ \\
$\mathrm{Fe}-\mathrm{W}$ & $\mathrm{Fe}$ & $\begin{array}{l}\text { Distilled water } \\
\mathrm{Ml}-\mathrm{Mg}\end{array}$ \\
$\mathrm{Al}-\mathrm{Mg}+\mathrm{Al}$ & $\mathrm{Al}$ & $\mathrm{Mg}\left(\mathrm{CH}_{3} \mathrm{COO}\right)_{2} 0.10 \mathrm{~mol} / \mathrm{l}$ \\
$\mathrm{Al}-\mathrm{W}$ & $\mathrm{Mg}\left(\mathrm{CH}_{3} \mathrm{COO}\right)_{2} 0.10 \mathrm{~mol} / \mathrm{l}$ with \\
$\mathrm{Ti}-\mathrm{Mg}{ }^{*}$ & $\mathrm{Al}$ & $\begin{array}{l}\text { Distilled water } \\
\mathrm{Mg}\left(\mathrm{CH}_{3} \mathrm{COO}\right)_{2} 0.10 \mathrm{~mol} / \mathrm{l}\end{array}$ \\
\hline
\end{tabular}

*: The conditions selected in the previous section.

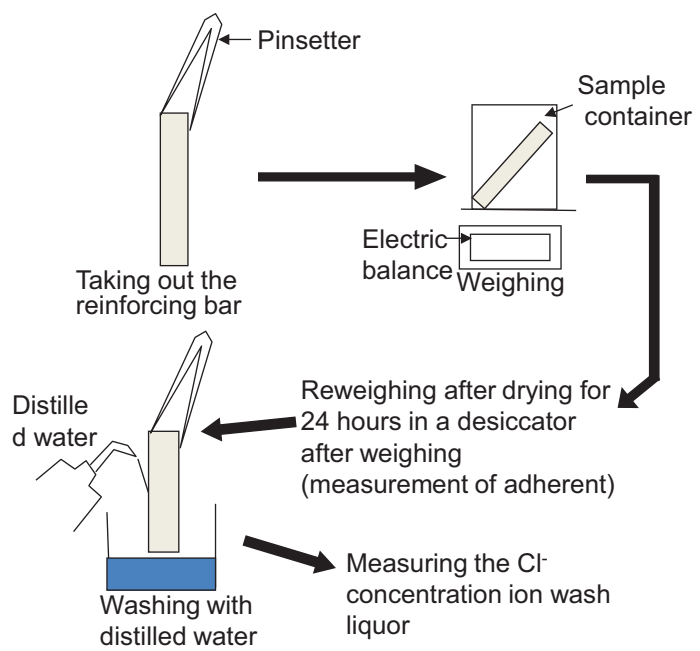

Figure 15. Outline of the measurement method of $\mathrm{Cl}^{-}$-concentration around a steel bar.

\subsection{Result and discussion using Type-C specimens}

The results of ratio of surface coating and deposition depth are shown in Figures 16 and 17, respectively. From these result, it is confirmed that the existence of $\mathrm{Mg}$ in the external solution is important to obtain a higher ratio of surface coating and a deeper depth of deposition. Also, $\mathrm{Fe}-\mathrm{Mg}+\mathrm{Al}$ and $\mathrm{Al}-\mathrm{Mg}$ had better precipitation situation of the electrodeposits. The chemical composition of each electrodeposits obtained by X-ray diffraction is shown in Table 7. It is considered that these chemical compounds are poorly soluble and chemically stable materials.

To evaluate the elution situation, the elution quantity was investigated and compared with the estimation from the integrated current. The results are shown in Figure 18. From the result, it can be said that the elution of external the electrode was around $0.01 \%$ compared to the electrode and that the influence of the charging direct current for 14 days was quite small. Therefore, it can be concluded that these electrodes have enough durability during 14 days of charging. Additionally, the quantity of elution can be estimated by the integrated current.

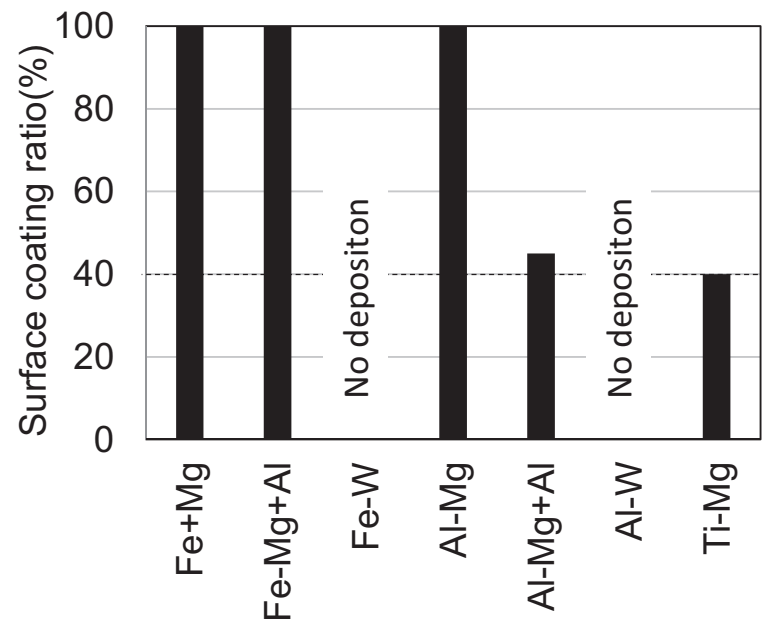

Kinds of external electrode and solution

Figure 16. Ratio of surface coated by electrodeposits using different external electrodes and solutions (titanium is usually used in the case of electrodeposition).

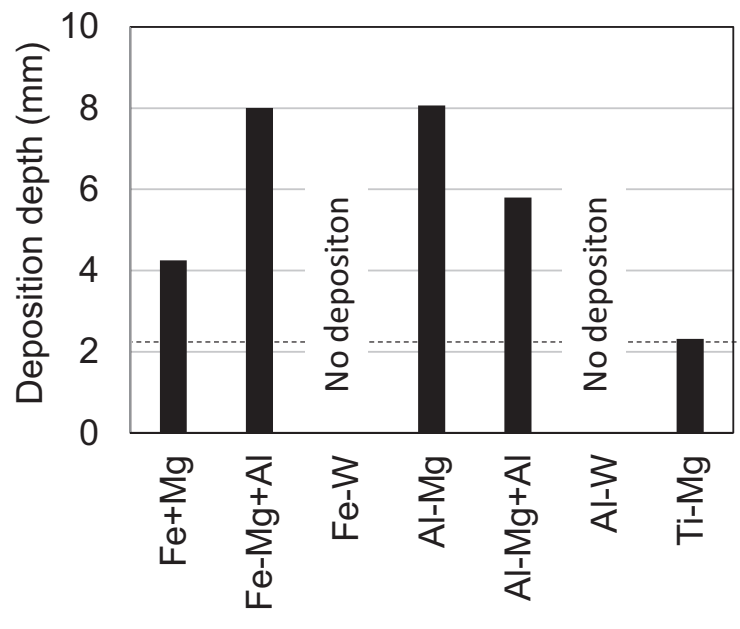

Kinds of external electrode and solution

Figure 17. Deposition depth of electrodeposits using different external electrodes and solutions (titanium is usually used in the case of electrodeposition).

Table 7. Chemical compounds of electrodeposits.

\begin{tabular}{ll}
\hline $\begin{array}{l}\text { External electrode } \\
\text { and solution }\end{array}$ & \multicolumn{1}{c}{ Chemical compound } \\
\hline Fe-Mg & $\mathrm{Fe}_{6}(\mathrm{OH})_{12}-\left(\mathrm{CO}_{3}\right)$ \\
& $\mathrm{Mg}(\mathrm{OH})_{2}$ \\
$\mathrm{Fe}-\mathrm{Mg}+\mathrm{Al}$ & $\mathrm{MgAl}(\mathrm{OH})_{14}-\mathrm{xH}_{2} \mathrm{O}$ \\
& $\mathrm{Fe}_{6}(\mathrm{OH})_{12}-\left(\mathrm{CO}_{3}\right)$ \\
& $\mathrm{Mg}(\mathrm{OH})_{2}$ \\
$\mathrm{Fe}-\mathrm{W}$ & --- \\
$\mathrm{Al}-\mathrm{Mg}$ & $\mathrm{MgAl}(\mathrm{OH})_{14}-\mathrm{xH}_{2} \mathrm{O}$ \\
$\mathrm{Al}-\mathrm{Mg}+\mathrm{Al}$ & $\mathrm{Mg}(\mathrm{OH})_{2}$ \\
$\mathrm{Al}-\mathrm{W}$ & $\mathrm{MgAl}(\mathrm{OH})_{14}-\mathrm{xH}_{2} \mathrm{O}$ \\
Ti-Mg & $\mathrm{Mg}(\mathrm{OH})_{2}$ \\
\hline
\end{tabular}




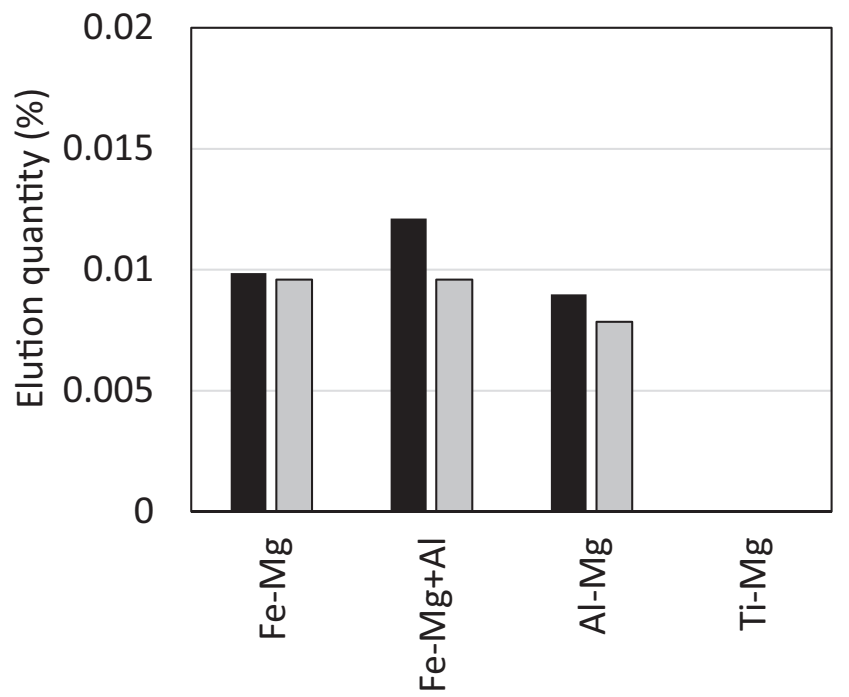

Kinds of external electrode and solution

Figure 18. Elution quantity using different external electrodes and solutions (titanium is usually used in electrodeposition).

\subsection{Resistivity against $\mathrm{Cl}^{-}$penetration}

Figure 19 shows the $\mathrm{Cl}^{-}$penetration depth in the mortar after submerging the specimen in $10 \mathrm{wt} \%$ $\mathrm{oNaCl}$ solution. From the result, it is clear that the electrodeposition using the $\mathrm{Fe}$ electrode with magnesium acetate and colloidal alumina, or $\mathrm{Al}$ electrode with magnesium acetate solution, had higher repair effect to improve resistivity against $\mathrm{Cl}^{-}$ penetration after repairing. This result could be also confirmed by the $\mathrm{Cl}^{-}$concentration around the steel bar as shown in Figure 20.

\subsection{Comprehensive evaluation}

Table 8 shows the comprehensive evaluation of $\mathrm{Fe}$ or Al electrode for the electrodeposition method. Al electrode combined with the magnesium acetate solution showed higher performance than the other combinations, even compared with the conventional condition using a titanium electrode.

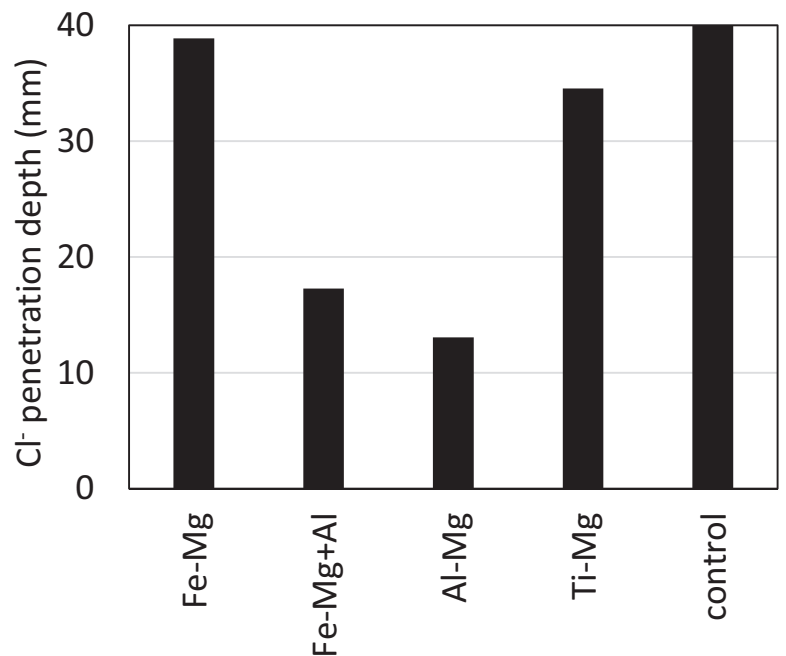

Kinds of external electrode and solution

Figure 19. $\mathrm{Cl}^{-}$penetration depth after submerging in $\mathrm{NaCl}$ solution after electrodeposition with different external electrodes and solutions (titanium is usually used in electrodeposition).

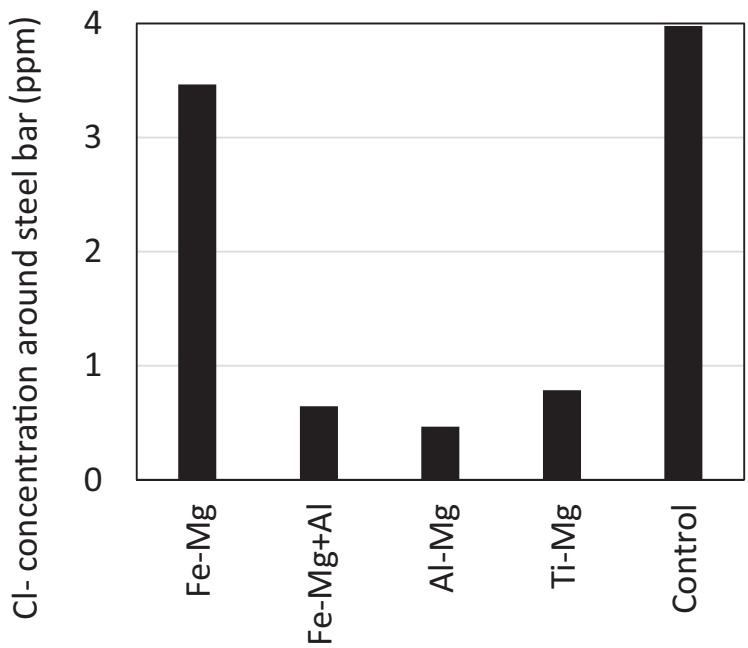

Kinds of external electrode and solution

Figure 20. $\mathrm{Cl}^{-}$around steel bar after submerging in $\mathrm{NaCl}$ solution after electrodeposition with external electrode and solution (titanium is usually used in electrodeposition).

Table 8. Comprehensive evaluations of external electrode and external solution for electrodeposition.

\begin{tabular}{|c|c|c|c|c|c|}
\hline \multirow[t]{2}{*}{$\begin{array}{l}\text { External } \\
\text { electrode }\end{array}$} & \multirow[t]{2}{*}{ External solution } & \multicolumn{2}{|c|}{$\begin{array}{c}\text { Precipitated situation } \\
\text { of electrodeposits }\end{array}$} & \multirow{2}{*}{$\begin{array}{c}\begin{array}{c}\text { Substance } \\
\text { penetrability }\end{array} \\
\begin{array}{c}\text { Against chloride } \\
\text { attack }\end{array}\end{array}$} & \multirow[t]{2}{*}{$\begin{array}{c}\text { Comprehensive } \\
\text { evaluation }\end{array}$} \\
\hline & & $\begin{array}{l}\text { Surface } \\
\text { coating }\end{array}$ & $\begin{array}{l}\text { Crack } \\
\text { closure }\end{array}$ & & \\
\hline $\mathrm{Fe}$ & $\mathrm{Mg}\left(\mathrm{CH}_{3} \mathrm{COO}\right)_{2} 0.10 \mathrm{~mol} / \mathrm{l}$ & () & ○ & $\bigcirc$ & O \\
\hline $\mathrm{Fe}$ & $\mathrm{Mg}\left(\mathrm{CH}_{3} \mathrm{COO}\right)_{2} 0.10 \mathrm{~mol} / \mathrm{l}$ and Colloidal Alumina & () & () & $\bigcirc$ & O \\
\hline $\mathrm{Fe}$ & Distilled water & $\times$ & $\times$ & $\times$ & $x$ \\
\hline Al & $\mathrm{Mg}\left(\mathrm{CH}_{3} \mathrm{COO}\right)_{2} 0.10 \mathrm{~mol} / \mathrm{l}$ & () & () & () & () \\
\hline $\mathrm{Al}$ & $\mathrm{Mg}\left(\mathrm{CH}_{3} \mathrm{COO}\right)_{2} 0.10 \mathrm{~mol} / \mathrm{l}$ and Colloidal alumina & $\bigcirc$ & $\bigcirc$ & $\bigcirc$ & $\bigcirc$ \\
\hline Al & Distilled water & $\times$ & $\times$ & $\times$ & $\times$ \\
\hline $\mathrm{Ti}$ & $\mathrm{Mg}\left(\mathrm{CH}_{3} \mathrm{COO}\right)_{2} 0.10 \mathrm{~mol} / \mathrm{l}$ & - & - & - & \\
\hline
\end{tabular}

Compared to titanium electrode; $\bigcirc$ means improved; Omeans the same; $\times$ means worse. 


\section{CONCLUSIONS}

The objective of present paper was to investigate the electrodeposition conditions such as the external solution and the external electrode for repairing reinforced concrete. The following conclusions were derived from this study.

(1) The repair effects of electrodeposition such as crack closure or resistance of substance penetrability are largely influenced by the solubility of the electrodeposits and the $\mathrm{pH}$ of external solution as seen from the results of experimental and theoretical investigations. The external solution containing appropriate cations such as $\mathrm{Mg}^{2+}, \mathrm{Zn}^{2+}$, or $\mathrm{Ca}^{2+}$ was found to be better as they can produce poorly soluble substance as electrodeposits in cracks or on the concrete surface. Also, it was found that the use of the salt of a weak acid as the external solution was effective in controlling the $\mathrm{pH}$ of the external solution during the application of a direct current between the steel bars and the external electrode.

(2) Lower concentration of the external solution resulted in dense electrodeposits and better crack closure, but the depth of crack closure with a lower concentration of the external solution became smaller than that with a higher concentration. So an appropriate concentration of the external solution of $0.10 \mathrm{~mol} / \mathrm{l}$ concentration was found to give the best repair effects in the case of magnesium acetate solution.

(3) The most suitable electrodeposition conditions to repair deteriorated concrete consisted of a magnesium acetate based external solution with an aluminum sacrificial electrode.

\section{REFERENCES}

Grant, J. (1969). Hach's chemical dictionary. New York: McGraw-Hill Book Company.

Otsuki, N., Nagataki, S., \& Nakashita, K. (1992). Evaluation of $\mathrm{AgNO}_{3}$ solution spray method for measurement of chloride penetration into hardened cementitious matrix materials. ACl Materials Journal, 89(64), 587-592.

Yokoda, M., Sasaki, H., \& Fukute, T. (1992).

Rehabilitation and protection of marine concrete member using electrodeposition method.

Proceedings of the International RILEM/CSIRO/ ACRA Conference on Rehabilitation of Concrete Members, RILEM, Melbourne, pp. 213-222. 